\title{
Appraisal of clinical practice guidelines on the management of obstetric perineal lacerations and care using the AGREE II instrument
}

\author{
Nygaard, Christiana C ; Tsiapakidou, Sofia ; Pape, Janna ; Falconi, Gabriele ; Betschart, Cornelia ; \\ Pergialiotis, Vasilios ; Doumouchtsis, Stergios K
}

\begin{abstract}
Pelvic floor trauma during childbirth is highly prevalent and is associated with long term risks of incontinence and pelvic organ prolapse. Societies and organizations have published clinical guidelines in order to standardise and improve the management of perineal care. The aim of this study was to systematically evaluate the quality of clinical guidelines on obstetric perineal trauma and care using the AGREE II instrument. We searched Medline, PubMed, Web of Science and ScienceDirect databases from inception until the 15th of December 2018 using the terms "guideline" OR "guidelines", OR "guidance", OR "recommendation" AND "obstetric anal sphincter injury", OR "perineal laceration" OR "perineal tear" OR "perineal trauma" OR "vaginal tear". Twelve guidelines were included, in English and Spanish. The assessment of the guidelines was performed using AGREE II by 5 appraisers. Ten guidelines scored more than $50 \%$, and 3 of them scored higher than $70 \%$. Two guidelines scored $<50 \%$ and were considered as low quality. Level of evidence and grade of recommendations were used by 7 guidelines of the 12 guidelines. Although some guidelines received high scores, there is space for improvement of the standards of guidelines.
\end{abstract}

DOI: https://doi.org/10.1016/j.ejogrb.2020.01.049

Posted at the Zurich Open Repository and Archive, University of Zurich

ZORA URL: https://doi.org/10.5167/uzh-195942

Journal Article

Accepted Version

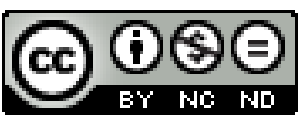

The following work is licensed under a Creative Commons: Attribution-NonCommercial-NoDerivatives 4.0 International (CC BY-NC-ND 4.0) License.

Originally published at:

Nygaard, Christiana C; Tsiapakidou, Sofia; Pape, Janna; Falconi, Gabriele; Betschart, Cornelia; Pergialiotis, Vasilios; Doumouchtsis, Stergios K (2020). Appraisal of clinical practice guidelines on the management of obstetric perineal lacerations and care using the AGREE II instrument. European Journal of Obstetrics, Gynecology, and Reproductive Biology, 247:66-72.

DOI: https://doi.org/10.1016/j.ejogrb.2020.01.049 


\section{Journal Pre-proof}

Appraisal of clinical practice guidelines on the management of obstetric perineal lacerations and care using the AGREE II instrument

Christiana C. Nygaard, Sofia Tsiapakidou, Janna Pape, Gabriele Falconi, Cornelia Betschart, Vasilios Pergialiotis, Stergios K.

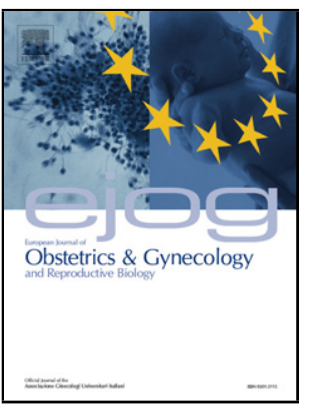

Doumouchtsis

PII: S0301-2115(20)30058-0

DOI: $\quad$ https://doi.org/10.1016/j.ejogrb.2020.01.049

Reference: $\quad$ EURO 11178

To appear in: $\quad$ European Journal of Obstetrics \& Gynecology and Reproductive Biology

Received Date: 1 December 2019

Revised Date: 30 January 2020

Accepted Date: $\quad 31$ January 2020

Please cite this article as: Nygaard CC, Tsiapakidou S, Pape J, Falconi G, Betschart C, Pergialiotis V, Doumouchtsis SK, Appraisal of clinical practice guidelines on the management of obstetric perineal lacerations and care using the AGREE II instrument, European Journal of Obstetrics and amp; Gynecology and Reproductive Biology (2020), doi: https://doi.org/10.1016/j.ejogrb.2020.01.049 
This is a PDF file of an article that has undergone enhancements after acceptance, such as the addition of a cover page and metadata, and formatting for readability, but it is not yet the definitive version of record. This version will undergo additional copyediting, typesetting and review before it is published in its final form, but we are providing this version to give early visibility of the article. Please note that, during the production process, errors may be discovered which could affect the content, and all legal disclaimers that apply to the journal pertain.

(C) 2019 Published by Elsevier. 


\section{Appraisal of clinical practice guidelines on the management of obstetric perineal lacerations and care using the AGREE II instrument}

Authors: Christiana C Nygaard ${ }^{1,2}$, Sofia Tsiapakidou ${ }^{3}$, Janna Pape ${ }^{4}$, Gabriele Falconi $^{5}$, Cornelia Betschart ${ }^{4}$, Vasilios Pergialiotis ${ }^{6}$, Stergios K Doumouchtsis ${ }^{1,6,7,8}$

1. Department of Obstetrics and Gynecology, Epsom and St Helier University Hospitals NHS Trust, London, United Kingdom

2. Department of Obstetrics and Gynecology, Pontifícia Universidade Católica do Rio Grande do Sul, Porto Alegre, Brazil

3. 1st Department of Obstetrics and Genecology, "Papageorgiou" General Hospital, Aristotle University of Thessaloniki, Thessaloniki, Greece

4. Department of Gynecology, University Hospital of Zurich, Zurich, Switzerland

5. Department of Obstetrics and Gynecology, "San Bortolo" Hospital, Vicenza, Italy

6. Laboratory of Experimental Surgery and Surgical Research N.S. Christeas. National and Kapodistrian University of Athens, Greece.

7. St George's University of London, London, United Kingdom

8. American University of the Caribbean, School of Medicine

On behalf of CHORUS: An International Collaboration Harmonising Outcomes, Research, and Standards in Urogynaecology and Women's Health (https://ichorus.org/)

Corresponding author: Christiana Campani Nygaard, Department of Obstetrics and Gynecology, Epsom and St Helier University Hospitals NHS Trust, London, United Kingdom. Dorking Rd, Epsom KT18 7EG, +447378274361, cnygcnyg@gmail.com 
Type of article: Systematic review

\section{Abstract:}

Pelvic floor trauma during childbirth is highly prevalent and is associated with long term risks of incontinence and pelvic organ prolapse. Societies and organizations have published clinical guidelines in order to standardise and improve the management of perineal care. The aim of this study was to systematically evaluate the quality of clinical guidelines on obstetric perineal trauma and care using the AGREE II instrument. We searched Medline, PubMed, Web of Science and ScienceDirect databases from inception until the $15^{\text {th }}$ of December 2018 using the terms "guideline" OR "guidelines", OR "guidance", OR "recommendation" AND "obstetric anal sphincter injury", OR "perineal laceration" OR "perineal tear" OR "perineal trauma" OR "vaginal tear". Twelve guidelines were included, in English and Spanish.The assessment of the guidelines was performed using AGREE II by 5 appraisers. Ten guidelines scored more than $50 \%$, and 3 of them scored higher than $70 \%$. Two guidelines scored $<50 \%$ and were considered as low quality. Level of evidence and grade of recommendations were used by 7 guidelines of the 12 guidelines. Although some guidelines received high scores, there is space for improvement of the standards of guidelines.

Abbreviations: American College of Obstetricians and Gynaecologists (ACOG), Austrian Urogynaecology Working Group (Austrian), Appraisal of Guidelines, Research and Evaluation II (AGREE II), Collaboration Harmonising Outcomes, Research, and Standards (CHORUS), German Society of Gynecology and Obstetrics ( German), Grading of Recommendations, Assessment, Development, and Evaluation (GRADE), México Instituto de Seguro Social (Mexican), National Collaborating Centre Women and Children Health /National Institute for Health and Care Excellence (NICE), Obstetric Anal Sphincter Injuries (OASIS), Queensland Clinical Guidelines (Queensland), The Royal College of Midwives (RCM), Royal College of Obstetricians and Gynaecologists (RCOG), Society of Obstetricians and Gynecologists of Canada (SOGC), Spanish National Healthcare System (Spanish), Department for Health and Ageing- Government of South Australia (South Australian), United States Preventive Services Task Force (USPSTF), World Health Organization (WHO) 
Keywords: AGREE II, guideline, OASIS, perineal tear, perineal trauma

\section{Introduction}

Pelvic floor trauma during childbirth is highly prevalent occurring in $85 \%$ of women (1). A recent anthropological model revealed a rise of fetal body weight and fetal head circumferences due to biological intergenerational selection and iatrogenic influences such as the higher conduct of C-sections worldwide. According to this model, higher rates of perineal trauma may be seen in the future. (2). Pelvic floor trauma at childbirth is associated with long term risks of incontinence and pelvic organ prolapse (3).

Third- and fourth-degree lacerations involve the anal sphincter complex and potentially the anal mucosa and are referred as Obstetric Anal Sphincter Injuries (OASIS). OASIS is a leading risk factor for subsequent anal incontinence, including flatus and stool incontinence. The impact of the latter condition on patient's quality of life could be detrimental; hence, prevention and appropriate management of OASIS is of paramount importance in current clinical practice. Evidence based knowledge and practice on prevention, recognition and management of this condition may improve prognosis (4).

Several risk factors for severe perineal lacerations have been described in the international literature(5) and preventive models of OASIS have been successfully implemented in an international level; however, the incidence of anal sphincter injury has reached a negative plateau that is difficult to overcome(6). Given that predictive 
models against pelvic floor trauma are lacking $(7,8)$, international and national societies and organizations have published clinical guidelines in order to standardise and improve the management of perineal care. Nonetheless, discrepancies in recommendations among different guidelines may exist.

The aim of this study was to evaluate the methodological quality of guidelines, their recommendations, and the research evidence supporting these recommendations using the Appraisal of Guidelines, Research and Evaluation II (AGREE II) instrument(9).

\section{Materials and Methods}

This study was undertaken by a Working Group led by CHORUS: An International Collaboration Harmonising Outcomes, Research, and Standards in Urogynaecology and Women's Health ( https://i-chorus.org/) An informed consent form was not required for this study.

The literature was systematically reviewed to identify international and national guidelines on the management of perineal trauma and obstetric anal sphincter injuries (OASIS). We searched Medline, PubMed, Web of Science and ScienceDirect databases from inception until the $15^{\text {th }}$ of December 2018. Search strategies and results are shown in the PRISMA flow diagram (Fig. 1). We used the following MeSH terms: "guideline" OR "guidelines", OR "guidance", OR "recommendation" AND "obstetric anal sphincter injury", OR "perineal laceration" OR "perineal tear" OR "perineal trauma" OR "vaginal tear", NOT "case reports", NOT "comment", NOT "editorial”, NOT "letter". A further manual search was performed in websites of national and international societies and organisations as well as reviewing references of key articles in this topic. The latest version of guidelines was used in cases where more 
than one guideline or updates were available. The final decision about inclusion of guidelines was based on authors' consensus.

The assessment was performed using AGREE II tool(9) which is a validated instrument used to appraise the methodological quality of guidelines. It includes 23 items, each scored on a 7-point scale with gradings 0-3 considered as unsatisfactory quality grading 4 as neutral and grading 5-7 as satisfactory quality. The items are grouped in six domains: 1) scope and purpose; 2) stakeholder involvement; 3) rigour of development; 4) clarity of presentation; 5) applicability; and 6) editorial independence. Five appraisers independently evaluated the guidelines in English included in the review. Three appraisers evaluated the guideline in Spanish.

Domain quality scores were calculated by summing the item scores in a given domain and converting the number into a standardised percentage of the maximum score that can be obtained for that domain. Discrepancies of more than three points on each item on the original 7-point scale were discussed in a consensus meeting in line with previous studies (10) (11). The AGREE II consortium has not set specific cutoff scores to differentiate between high and low-quality guidelines. Domain scores < $50 \%$ were considered as low quality. With regards to recommending a guideline based on the score, some articles used the mean of all six domains and guidelines were 'recommended' if the result was above $60 \%$, 'recommended with modifications' if the score was between 30 and $60 \%$ and 'not recommended' if the score was lower than $30 \%$ (11). Fleiss' kappa coefficient was used to determine the overall agreement and significance. A kappa value of 0.00 indicates poor, 0.00-0.20 slight, 0.21-0.40 fair, 0.41-0.60 moderate, $0.61-0.80$ substantial and 0.81 to 1.00 , almost perfect agreement (12). 
The guidelines' assessment of the quality of the evidence and recommendations were reviewed. Different systems and classifications were used by the different guidelines: U.S. Preventive Services Task Force (USPSTF)(13) assigns one of five letter grades (A, B, C, D, or I) for level of recommendation, Grading of Recommendations, Assessment, Development, and Evaluation (GRADE) (14) uses classification of evidence levels $(1++, 1+, 1-, 2++, 2+, 2-, 3,4)$ and grades of recommendation ( $A, B, C$ and $D)$; and The Evaluation of Evidence criteria described in the Canadian Task Force on Preventive Health Care(15) that uses quality of evidence ( I, II-1, II,-2, II-3, III) and classification of recommendation ( $A, B, C, D, L)$.

\section{Results}

The literature search identified initially 35 guidelines, and 12 were finally included. Local hospital guidelines or patient brochures were excluded (Figure 1). Year of publication ranged from 2010 to 2018. Eleven guidelines are in English, and 1 guideline is in Spanish language (Mexican(16)). The characteristics of the guidelines included are presented in Table 1. Seven out of the twelve guidelines were developed and published by specialist societies ACOG(17), Austrian(18), German(19), $\operatorname{RCOG}(20)$, SOGC(21)and RCM(22) and the others were developed by national or international institutions or organisations. Six of the included guidelines provided specific guidance on the management of OASIS (Mexican(16), ACOG(17), Austrian(18), German(19), RCOG(20), SOGC(21)) and 6 on the care of obstetric perineal trauma in general (NICE(23), South Australian(24), Queensland(25), $\mathrm{RCM}(22)$, Spanish(26), $\mathrm{WHO}(27))$.

\subsection{Appraisal of guidelines}


The total score of each domain and overall quality of the guidelines are presented in Table 2. Ten guidelines scored more than $50 \%$, and 3 of them scored higher than $70 \%$ (Spanish(26), WHO(27), RCOG(20)). Two guidelines scored < 50\% and were considered as low quality (Mexican(16), RCM(22)). The Spanish(26) guideline achieved the overall highest score (82.4\%) and the $\mathrm{RCM}(22)$ the lowest (36.8\%). Six guidelines achieved scores greater than $60 \%$ and were therefore recommend by the appraisers whilst 6 guidelines scored between $30 \%$ and $60 \%$ and were 'recommended with modifications'. The overall interrater agreement demonstrated a high variation with slight to substantial agreement $(0.12-0.77)$.

\subsubsection{Scope and Purpose}

The mean score in this domain was $67.0 \%$ (range $28.8-84.4 \%$ ). The German (19) guidelines achieved the highest score (84.4\%). Only two guidelines scored below $50 \%$ (Mexican(16) and $\mathrm{RCM}(22)$ ).

\subsubsection{Stakeholder involvement}

The mean score in this domain was $55.8 \%$ with a wide variation among the guidelines (range 31.1-83.3\%).Three guidelines scored below 50\%(ACOG(17), Mexican(16), $R C M(22)$ and the Spanish(26) guideline scored the highest, at 83.3\%. The Spanish guideline involved stakeholders from very different areas including obstetricians/gynaecologists, midwives, pharmacists, general practitioners, a specialist in preventive medicine, paediatricians, a neonatologist, anaesthetists, epidemiologist, specialist in public health, journalist, documentalist, and an electronics technician. 


\subsubsection{Rigour of development}

This domain comprises 7 items that relate to the process of gathering and synthesizing the evidence, to the methods to formulate the recommendations, and to update them. The mean score in this domain was fairly high with $68.8 \%$ (range 43.694.3\%). Three guidelines achieved a very high standard in their development by applying systematic methods to search for evidence and yielding higher scores than 90\% (Canadian(21), Spanish(26) and $\mathrm{WHO}(27)$ ). The domains "Clarity of Presentation" achieved the highest overall score. Level of evidence and grade of recommendations were used by 7 guidelines. and a summary of the main recommendations is presented in Table 3. The $\mathrm{WHO}(27)$ guideline reported the use of GRADE(14), although GRADE scores were not actually attached to each recommendation.

\subsubsection{Clarity of Presentation}

The mean score was $68.8 \%$ (44.4-91.1\%) The Canadian (21) guideline achieved the highest score. The Mexican(16) guideline was the only guideline that scored below $50 \%$. The recommendations were easily identifiable in most of the guidelines which is important for clinical applicability and use in daily practice.

\subsubsection{Applicability}

The mean score of the domains was $56.7 \%(31.9-80.0 \%)$. This was the domain where most guidelines were considered as low quality as four guidelines scored below 50\% (ACOG(17), Mexican(16), NICE(23), RCM(22)). The Spanish(26) guidelines 
achieved the highest score (80\%) in this domain. Most guidelines did not report on the facilitators to implementation of recommendations and resource implications.

\subsubsection{Editorial Independence}

This domain showed the overall lowest score (48.5\%, range $25-70 \%)$ and half of the guidelines were considered of poor quality. The German(19) and Spanish(26) guidelines scored the highest scores.

\subsection{Guidelines Recommendations}

The recommendations of the seven guidelines that described the level of evidence and grade of recommendations are described in Table 3. For the prevention of obstetric tears, the main recommendation used by 5 of those guidelines was the use of warm compresses in the second stage of labour. The use of restrictive episiotomy was also recommended by 4 guidelines. The mediolateral technique for episiotomy was recommended by 7 guidelines with different levels of recommendations. Regarding OASIS, repair of full-thickness external anal sphincter laceration using end to end or overlap technique was recommended by 4 of the guidelines. The use of prophylactic antibiotics was recommended in 5 guidelines. For the repair of the internal anal sphincter 3.0 Polyglactin or 3.0 Monofilament Polydioxanone can be used according to 4 guidelines.

\subsection{Discussion}

To our knowledge, this is the first study to evaluate guidelines on perineal care. The quality of the evaluated guidelines on the management of perineal tears and care was found to be highly variable. There are wide variations in global obstetric practice in relation to prevention, diagnosis and management of perineal lacerations. This is 
reflected by the areas of emphasis in different guidelines, such as prevention in the Spanish(26) guideline or the surgical management of OASIS in the RCOG(20) guideline. The assessment of the quality of the evidence varies widely among the different guidelines as different tools were used (USPSTF, GRADE, qualitative Evidence) which renders a direct comparison of the strength of the recommendations impossible.

The domain "Rigor of Development" achieved the highest mean score in all the guidelines, although the evidence presented is not uniform. For instance, perineal massage in the second stage of labor for prevention of tears is recommended by one guideline (ACOG(17)) and is contraindicated by 2 other guidelines (Spanish(26) and $\operatorname{NICE}(23))$.

On the other hand, the mediolateral type of episiotomy was recommended by the 7 guidelines that assessed of the quality of the evidence and the use of restrictive episiotomy by 4 guidelines (ACOG (17), Austrian(18), Spanish(26) and NICE(23)). Warm compresses in the second stage for prevention of trauma was recommended by 5 guidelines with high quality of evidence. Recommendations regarding OASIS management were more consistent among the guidelines including the use of antibiotics, the choice of suture and technique for full-thickness repair of the external sphincter laceration. Evidence-based counselling of women after OASIS in respect to future childbirth and delivery mode was a topic in the RCOG(20), the Austrian(18), the SOGC(21), and the Queensland(25) guideline. In case of bowel symptoms after OASIS, these guidelines discuss the option of elective caesarean birth for future childbirth as part of patients' counselling. As individual risk models for birth-related pelvic floor injuries are slowly emerging $(5,6,7)$, they do not feature in guidelines as yet. Today, guidelines serve as generally applicable clinical guides, however individual 
risk models are emerging. The pelvic dimensions, spinal curvature, maternal obesity, connective tissue failures, perineal body length, genital hiatus size or fetal weight estimations are associated with the incidence of birth-related pelvic floor injuries(28). However, these individual risk factors are not considered in the guidelines and did not influence the guidelines recommendations. The AGREE II tool(9) as a methodological tool does not include evaluation of the quality of the content.

"Editorial independence" had the lowest overall score and include the disclosure of interested and funding, hence, raising concerns about the potential conflicts that would arise from industry-funded projects Simple clarifications and statements in the text could address it.

The second last lower score was in "Stakeholder Involvement" domain, which evaluates the presence of individuals of all relevant professional groups, preferences of the target population and target users, as it is important to base recommendations on a multidisciplinary consensus. This domain tends to reach low scores in other guidelines as found in our previous study (10). "Applicability" was another domain with overall low scores, and it is related to the implementation of the recommendations. There is a need to facilitate this process providing tools and advice on resources(29).

All appraisers are doctors working in OB/GYN while other publications scoring guidelines with AGREE II(9) did not include healthcare professionals (30). This enhances a critical view of the clinical aspects of the guidelines. The guidelines included represent different health systems and a range of models of care. Finally, they were evaluated with a standardized method using a validated tool(30).

Concerning the study limitations, guidelines that were published in Medline, PubMed, Web of Science and ScienceDirect were considered as eligible for inclusion in the present study as these represent easily accessible guidance that is likely to be 
partially, or in full, used by practitioners, or various other national societies and organizations for clinical practice. However, a number of other guidelines may have been published that were not evaluated in this study. The AGREE II tool(9) focuses essentially on the appraisal of the development process and not on the critical evaluation of the quality of the content. Another limitation is that the appraisers were not blinded to the society developing the guideline, and the they might have been influenced in their scoring by knowing the publishing organisation.

\subsection{Conclusions}

There is space for improvement of the standards of guidelines, as no guideline completely followed the standardized guideline development methods (AGREE-II(9)). Tools such as AGREE II(9) are useful to evaluate the quality of the existing guidelines and can be considered as a guidance tool, for developing national and international guidelines. Harmonization of guidelines may also be considered by institutions and societies based on the highest quality available evidence and such tools may assist in this direction.

\section{Author's contributions:}

C C Nygaard: design, planning, conduct, data analysis, and manuscript writing

S Tsiapakidou: design, planning, conduct, data analysis

J Pape: conduct and manuscript writing

G Falconi: conduct and manuscript writing

C Betschart: design, planning, conduct, and manuscript writing

V Pergialiotis: conduct, and manuscript writing

SK Doumouchtis: design, planning, conduct, and manuscript writing

Conflict of interest: None 


\section{References}

1. $\quad$ Frohlich J, Kettle C. Perineal care. BMJ Clin Evid. 2015;2015.

2. Mitteroecker P, Windhager S, Pavlicev M. Cliff-edge model predicts intergenerational predisposition to dystocia and Caesarean delivery. Proceedings of the National Academy of Sciences of the United States of America. 2017;114(44):11669-72. 3. Thomas V, Shek KL, Guzman Rojas R, Dietz HP. Temporal latency between pelvic floor trauma and presentation for prolapse surgery: a retrospective observational study. International urogynecology journal. 2015;26(8):1185-9.

4. Koelbl H IT, Salvatore S, Laterza RM, Lowry A, Sievert, KD ea. Pathophysiology of urinary incontinence, faecalincontinence and pelvic organ prolapse. In: Abrams $\mathrm{P}$, Cardozo L, Khoury S, Wein A, editors. Incontinence. 5th ed. [place unknown]: ICUD-EAU; 2013. p. 261-359.

5. Pergialiotis V, Vlachos D, Protopapas A, Pappa K, Vlachos G. Risk factors for severe perineal lacerations during childbirth. Int J Gynaecol Obstet. 2014;125(1):6-14. 6. Jango H, Westergaard HB, Kjaerbye-Thygesen A, Langhoff-Roos J, Lauenborg J. Changing incidence of obstetric anal sphincter injuries-A result of formal prevention programs? Acta Obstet Gynecol Scand. 2019;98(11):1455-63.

7. Rostaminia G, Peck JD, Van Delft K, Thakar R, Sultan A, Shobeiri SA. New Measures for Predicting Birth-Related Pelvic Floor Trauma. Female Pelvic Med Reconstr Surg. 2016;22(5):292-6.

8. Jelovsek JE, Chagin K, Gyhagen M, Hagen S, Wilson D, Kattan MW, et al. Predicting risk of pelvic floor disorders 12 and 20 years after delivery. American journal of obstetrics and gynecology. 2018;218(2):222 e1- e19.

9. AGREE Enterprise. AGREE II instrument 2017. Available from:

https://www.agreetrust.org/wp-content/uploads/2017/12/AGREE-II-Users-Manualand-23-item-Instrument-2009-Update-2017.pdf. Acessed on 01 November 2018

10. Pape J, Falconi G, De Mattos Lourenco TR, Doumouchtsis SK, Betschart C. Variations in bladder pain syndrome/interstitial cystitis (IC) definitions, pathogenesis, diagnostics and treatment: a systematic review and evaluation of national and international guidelines. Int Urogynecol J. 2019.

11. Wang Y, Ye ZK, Li JF, Cui XL, Liu LH. Heparin-induced thrombocytopenia: A critical appraisal of clinical practice guidelines with the AGREE II instrument. Thromb Res. 2018;166:10-8.

12. Landis JR, Koch GG. The measurement of observer agreement for categorical data. Biometrics. 1977;33(1):159-74.

13. U.S. Preventive Services Task Force Available from https://www.uspreventiveservicestaskforce.org/ Acessed on 15 of December 2018. 14. Brozek JL, Akl EA, Jaeschke R, Lang DM, Bossuyt P, Glasziou P, et al. Grading quality of evidence and strength of recommendations in clinical practice guidelines: Part 2 of 3. The GRADE approach to grading quality of evidence about diagnostic tests and strategies. Allergy. 2009;64(8):1109-16.

15. Bell N, Connor Gorber S, Tonelli M, Pottie K, Singh H, Joffres M, et al. From ABCs to GRADE: Canadian Task Force on Preventive Health Care's new rating system for clinical practice guidelines. Can Fam Physician. 2013;59(12):1282-9. 
16. Diagnóstico, Prevención y Tratamiento de Episiotomía Complicada México Instituto de Seguro Social 2013 Available from

http://www.imss.gob.mx/sites/all/statics/guiasclinicas/608GER.pdf Acessed on 15 of December 2018.

17. American College of O, Gynecologists' Committee on Practice B-O. Practice Bulletin No. 165: Prevention and Management of Obstetric Lacerations at Vaginal Delivery. Obstet Gynecol. 2016;128(1):e1-e15.

18. Aigmueller T, Umek W, Elenskaia K, Frudinger A, Pfeifer J, Helmer H, et al. Guidelines for the management of third and fourth degree perineal tears after vaginal birth from the Austrian Urogynecology Working Group. Int Urogynecol J. 2013;24(4):553-8.

19. Aigmueller T, Bader W, Beilecke K, Elenskaia K, Frudinger A, Hanzal E, et al. Management of 3rd and 4th Degree Perineal Tears after Vaginal Birth. German Guideline of the German Society of Gynecology and Obstetrics (AWMF Registry No. 015/079, October 2014). Geburtshilfe Frauenheilkd. 2015;75(2):137-44.

20. RCOG The Management of Third- and Fourth-Degree Perineal Tears Green-top Guideline No. 29 June 2015 Available from https://www.rcog.org.uk/globalassets/documents/guidelines/gtg-29.pdf Accessed on 15 of December 2018.

21. Harvey MA, Pierce M, Alter JE, Chou Q, Diamond P, Epp A, et al. Obstetrical Anal Sphincter Injuries (OASIS): Prevention, Recognition, and Repair. J Obstet Gynaecol Can. 2015;37(12):1131-48.

22. RCM Care of Perineum Evidence Based Guidelines for Midwifery-Led Care in Labor Available from https://www.rcm.org.uk/media/2278/evidence-basedguidelines-care-of-the-perineum.pdf Accessed on 15 of December 2018.

23. NICE Intrapartum Care. Care of healthy women and their babies during childbirth Clinical guideline 190 Available from https://www.nice.org.uk/guidance/cg190 Accessed on 15 of December 2018.

24. Perineal Care Department for Health and Ageing Available from https://www.health.qld.gov.au/_data/assets/pdf_file/0022/142384/g-pericare.pdf Accessed on 15 of December.

25. Queensland Clinical Guidelines Perineal care -Maternity and Neonatal Clinical Guidelines Available from https://www.health.qld.gov.au/_data/assets/pdf_file/0022/142384/g-pericare.pdf Accessed on 15 of december 2018.

26. Clinical Practice Guideline on Care in Normal Childbirth. Quality Plan for the Spanish National Healthcare System of the Spanish Ministry for Health and Social Policy Available from https://portal.guiasalud.es/wpcontent/uploads/2018/12/GPC_472_Parto_Normal_Osteba_compl_en.pdf Accessed on 15 of December 2018

27. WHO recommendations Intrapartum care for a positive childbirth experience Available from

https://apps.who.int/iris/bitstream/handle/10665/260178/9789241550215-

eng.pdf;jsessionid=5F0DC00BDBD5465565C6087D44F88F93? sequence $=1$ Accessed on 15 of December 2018.

28. Berger MB, Doumouchtsis SK, DeLancey JO. Bony pelvis dimensions in women with and without stress urinary incontinence. Neurourol Urodyn. 2013;32(1):37-42. 29. Fischer F, Lange K, Klose K, Greiner W, Kraemer A. Barriers and Strategies in Guideline Implementation-A Scoping Review. Healthcare (Basel). 2016;4(3). 
30. Seto K, Matsumoto K, Kitazawa T, Fujita S, Hanaoka S, Hasegawa T. Evaluation of clinical practice guidelines using the AGREE instrument: comparison between data obtained from AGREE I and AGREE II. BMC Res Notes. 2017;10(1):716. 
Fig 1- PRISMA 2009 Flow Diagram

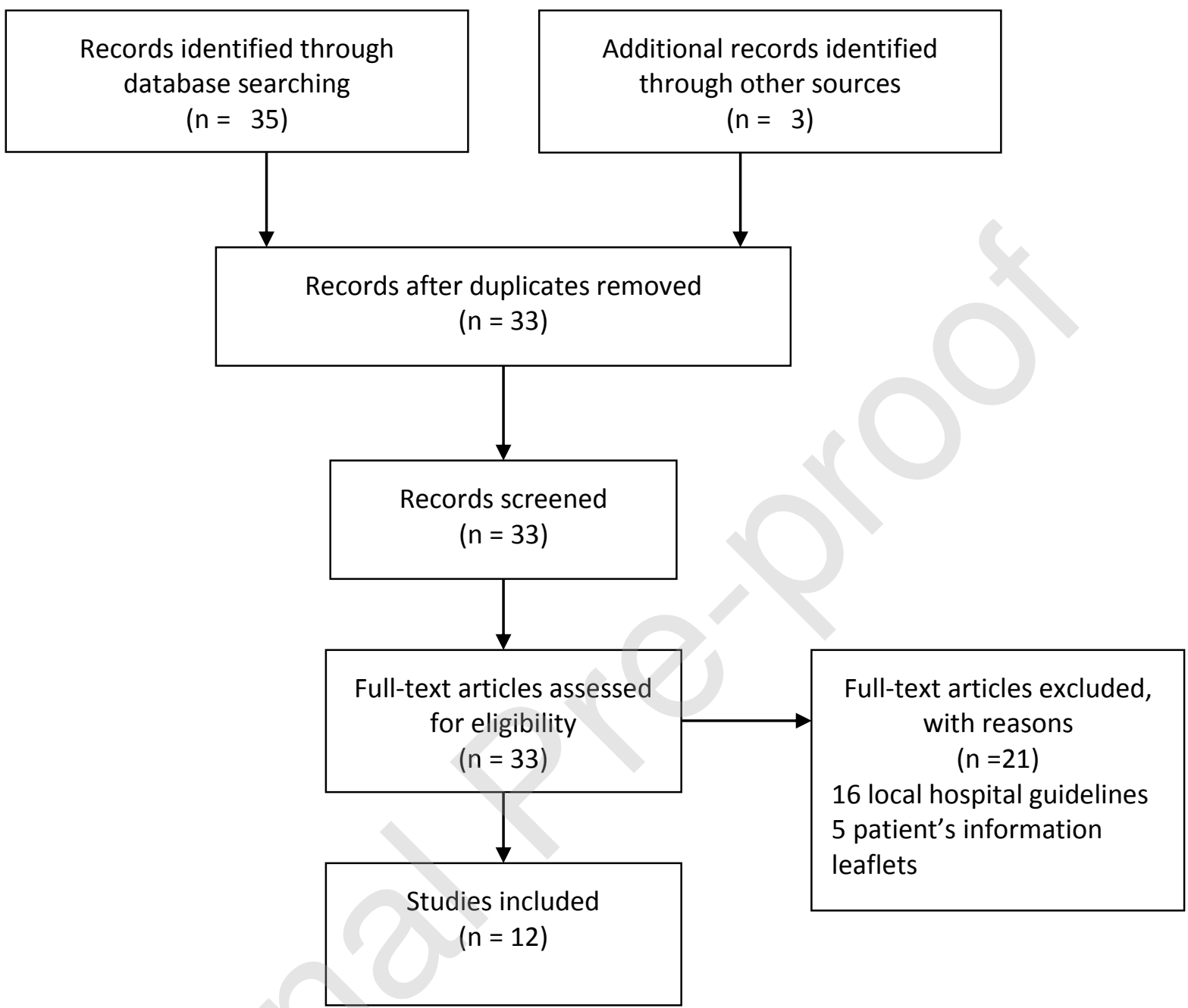

Table 1- Guidelines characteristics

\begin{tabular}{|c|c|c|c|c|}
\hline Guideline & $\begin{array}{l}\mathrm{Y} \\
\mathrm{e} \\
\text { ar }\end{array}$ & Organisation & $\begin{array}{l}\text { Quality of } \\
\text { evidence/ } \\
\text { Strength of } \\
\text { recommend } \\
\text { ation }\end{array}$ & $\begin{array}{l}\text { Abbrevi } \\
\text { ation }\end{array}$ \\
\hline $\begin{array}{l}\text { Prevention and Management of Obstetric Lacerations at Vaginal } \\
\text { Delivery- Practice Bulletin } 165\end{array}$ & $\begin{array}{l}2 \\
0 \\
1 \\
6\end{array}$ & $\begin{array}{l}\text { American College of } \\
\text { Obstetricians and } \\
\text { Gynaecologists }\end{array}$ & USPSTF & ACOG \\
\hline
\end{tabular}




\begin{tabular}{|c|c|c|c|c|}
\hline $\begin{array}{l}\text { The Management of Third- and Fourth-Degree Perineal Tears- } \\
\text { Green-top Guideline No. } 29\end{array}$ & $\begin{array}{l}2 \\
0 \\
1 \\
6\end{array}$ & $\begin{array}{l}\text { Royal College of } \\
\text { Obstetricians and } \\
\text { Gynaecologists }\end{array}$ & GRADE & $\mathrm{RCOG}$ \\
\hline $\begin{array}{l}\text { Guidelines for the management of third- and fourth-degree } \\
\text { perineal tears after vaginal birth from the Austrian } \\
\text { Urogynecology Working Group }\end{array}$ & $\begin{array}{l}2 \\
0 \\
1 \\
2\end{array}$ & $\begin{array}{l}\text { Austrian } \\
\text { Urogynaecology } \\
\text { Working Group }\end{array}$ & GRADE & Austrian \\
\hline $\begin{array}{l}\text { Management of 3rd and 4th Degree Perineal Tears after Vaginal } \\
\text { Birth. German Guideline of the German Society of Gynecology } \\
\text { and Obstetrics }\end{array}$ & $\begin{array}{l}2 \\
0 \\
1 \\
4\end{array}$ & $\begin{array}{l}\text { German Society of } \\
\text { Gynecology and } \\
\text { Obstetrics }\end{array}$ & NR & German \\
\hline Clinical Practice Guideline on Care in Normal Childbirth & $\begin{array}{l}2 \\
0 \\
1 \\
0\end{array}$ & $\begin{array}{l}\text { Spanish National } \\
\text { Healthcare System }\end{array}$ & $\begin{array}{l}\text { GRADE } \\
\text { SING/NICE } \\
\text { adaptation of } \\
\text { OXFORD }\end{array}$ & Spanish \\
\hline $\begin{array}{l}\text { Diagnóstico, Prevención y Tratamiento de Episiotomía } \\
\text { Complicada México Instituto de Seguro Social }\end{array}$ & $\begin{array}{l}2 \\
0\end{array}$ & $\begin{array}{l}\text { México Instituto de } \\
\text { Seguro Social }\end{array}$ & GRADE & Mexican \\
\hline $\begin{array}{l}\text { Obstetrical Anal Sphincter Injuries (OASIS): Prevention, } \\
\text { Recognition, and Repair Clinical Practice Guideline No. } 330\end{array}$ & $\begin{array}{l}2 \\
0 \\
1 \\
5\end{array}$ & $\begin{array}{l}\text { Society of } \\
\text { Obstetricians and } \\
\text { Gynecologists of } \\
\text { Canada }\end{array}$ & $\begin{array}{l}\text { Canadian } \\
\text { Task Force } \\
\text { on } \\
\text { Preventive } \\
\text { Health Care }\end{array}$ & SOGC \\
\hline Perineal care -Maternity and Neonatal Clinical Guidelines & $\begin{array}{l}2 \\
0\end{array}$ & $\begin{array}{l}\text { Queensland Clinical } \\
\text { Guidelines }\end{array}$ & NR & $\begin{array}{l}\text { Queensl } \\
\text { and }\end{array}$ \\
\hline $\begin{array}{l}\text { Intrapartum Care. Care of healthy women and their babies } \\
\text { during childbirth Clinical guideline } 190\end{array}$ & $\begin{array}{l}2 \\
0 \\
1 \\
7\end{array}$ & $\begin{array}{l}\text { National Collaborating } \\
\text { Centre Women and } \\
\text { Children Health } \\
\text { /National Institute for } \\
\text { Health and Care } \\
\text { Excellence }\end{array}$ & $\begin{array}{l}\text { GRADE/QUA } \\
\text { DAS }\end{array}$ & NICE \\
\hline Intrapartum care for a positive childbirth experience & $\begin{array}{l}2 \\
0\end{array}$ & $\begin{array}{l}\text { World Health } \\
\text { Organization }\end{array}$ & & WHO \\
\hline Perineal Care Department for Health and Ageing & $\begin{array}{l}2 \\
0 \\
1 \\
4\end{array}$ & $\begin{array}{l}\text { Department for Health } \\
\text { and Ageing- } \\
\text { Government of South } \\
\text { Australia }\end{array}$ & NR & $\begin{array}{l}\text { South } \\
\text { Australia } \\
\mathrm{n}\end{array}$ \\
\hline
\end{tabular}




\begin{tabular}{l|l|l|l|l}
\hline Care of Perineum Evidence Based Guidelines for Midwifery-Led & 2 & The Royal College of & NR & RCM \\
Care in Labor & 0 & Midwives & & \\
& 2 & & & \\
\hline
\end{tabular}

USPSTH- U.S. Preventive Services Task Force, NR- no reference, GRADE- Grading of Recommendations, Assessment, Development, and Evaluation

Table 2. Scores in each domain using AGREE II tool

\begin{tabular}{|c|c|c|c|c|c|c|c|c|}
\hline Guideline & $\begin{array}{c}\text { Scope } \\
\text { and } \\
\text { Purpose* }^{*}\end{array}$ & $\begin{array}{c}\text { Stakehold } \\
\text { er } \\
\text { Involveme } \\
\text { nt }^{\star}\end{array}$ & $\begin{array}{c}\text { Rigor of } \\
\text { Developm } \\
\text { ent }^{\star}\end{array}$ & $\begin{array}{c}\text { Clarity of } \\
\text { Presentati } \\
\text { on }^{\star}\end{array}$ & $\begin{array}{c}\text { Applicabili } \\
\text { ty* }^{\star}\end{array}$ & $\begin{array}{c}\text { Editorial } \\
\text { Independe } \\
\text { nce* }^{*}\end{array}$ & $\begin{array}{c}\text { Guideline } \\
\text { Overall } \\
\text { Score }\end{array}$ & $\begin{array}{c}\text { Recomme } \\
\text { ndation }\end{array}$ \\
\hline ACOG & $\begin{array}{l}67.8 \% \\
76(5-75)\end{array}$ & $\begin{array}{l}45.6 \% \\
56(15- \\
105)\end{array}$ & $\begin{array}{l}60.0 \% \\
161(35- \\
245)\end{array}$ & $\begin{array}{l}57.7 \% \\
67(15- \\
105)\end{array}$ & $\begin{array}{l}44.2 \% \\
73(20- \\
140)\end{array}$ & $\begin{array}{l}25 \% \\
25(10- \\
70)\end{array}$ & $50.0 \%$ & YwM \\
\hline RCOG & $\begin{array}{l}78.9 \% \\
86(15 \\
-105)\end{array}$ & $\begin{array}{l}55.6 \% \\
65(15 \\
-105)\end{array}$ & $\begin{array}{l}93.3 \% \\
231(3 \\
5-245)\end{array}$ & $\begin{array}{l}86.7 \% \\
93(15 \\
-105)\end{array}$ & $\begin{array}{l}72.5 \% \\
107 \\
(20- \\
140)\end{array}$ & $\begin{array}{l}68,3 \% \\
51 \\
(10- \\
70)\end{array}$ & $75.8 \%$ & Y \\
\hline Austrian & $\begin{array}{l}71.1 \% \\
79(15- \\
105)\end{array}$ & $\begin{array}{l}51.1 \% \\
61(15- \\
105)\end{array}$ & $\begin{array}{l}73.8 \% \\
190 \\
(35- \\
245)\end{array}$ & $\begin{array}{l}75.5 \% \\
83(15- \\
105)\end{array}$ & $\begin{array}{l}51.6 \% \\
82(20- \\
140)\end{array}$ & $\begin{array}{l}46.6 \% \\
38(10- \\
70)\end{array}$ & $61.6 \%$ & Y \\
\hline German & $\begin{array}{l}84.4 \% \\
91(15- \\
105)\end{array}$ & $\begin{array}{l}68.9 \% \\
77(15- \\
105)\end{array}$ & $\begin{array}{c}66.7 \% \\
175 \\
(35- \\
245)\end{array}$ & $\begin{array}{l}64.4 \% \\
73(15- \\
75)\end{array}$ & $\begin{array}{l}53.3 \% \\
84(20- \\
140)\end{array}$ & $\begin{array}{l}70.0 \% \\
52(10- \\
70)\end{array}$ & $67.9 \%$ & $Y$ \\
\hline Spanish & $\begin{array}{l}82.2 \% \\
89(15- \\
89)\end{array}$ & $\begin{array}{l}83.3 \% \\
90(15- \\
105)\end{array}$ & $\begin{array}{l}94.3 \% \\
233 \\
(35- \\
245)\end{array}$ & $\begin{array}{l}84.4 \% \\
91(15- \\
105)\end{array}$ & $\begin{array}{l}80.0 \% \\
116 \\
(20- \\
140)\end{array}$ & $\begin{array}{l}70.0 \% \\
52(10- \\
70)\end{array}$ & $82.4 \%$ & $Y$ \\
\hline Mexican & $\begin{array}{l}40.7 \% \\
31(9- \\
63)\end{array}$ & $\begin{array}{l}33.3 \% \\
27(9- \\
63)\end{array}$ & $\begin{array}{l}43.6 \% \\
76(21- \\
147)\end{array}$ & $\begin{array}{l}44.4 \% \\
33(9- \\
63)\end{array}$ & $\begin{array}{l}31.9 \% \\
35(84- \\
12)\end{array}$ & $\begin{array}{l}33.3 \% \\
18(6- \\
42)\end{array}$ & $37.9 \%$ & YwM \\
\hline SOGC & $\begin{array}{l}78.9 \\
\% \\
86 \\
(15- \\
105)\end{array}$ & $\begin{array}{l}58.9 \\
\% \\
68 \\
(15- \\
105)\end{array}$ & $\begin{array}{l}91.9 \\
\% \\
228 \\
(35- \\
245\end{array}$ & $\begin{array}{l}91.1 \\
\% \\
97 \\
(15- \\
105)\end{array}$ & $\begin{array}{l}75.8 \\
\% \\
111 \\
(20- \\
140)\end{array}$ & $\begin{array}{l}65.0 \\
\% \\
49 \\
(10- \\
70)\end{array}$ & $61.6 \%$ & $Y$ \\
\hline $\begin{array}{l}\text { Queensla } \\
\text { nd }\end{array}$ & $\begin{array}{l}58.9 \% \\
68(15- \\
105)\end{array}$ & $\begin{array}{l}58.8 \% \\
68(15- \\
105)\end{array}$ & $\begin{array}{l}50.0 \% \\
140(35- \\
245)\end{array}$ & $\begin{array}{l}58.9 \% \\
68(15- \\
105)\end{array}$ & $\begin{array}{l}60.0 \% \\
92(20-140)\end{array}$ & $\begin{array}{l}56.7 \% \\
44(10-70)\end{array}$ & $57.2 \%$ & YwM \\
\hline
\end{tabular}

Percentage, obtained score (minimum possible score- maximum possible score) 


\begin{tabular}{|c|c|c|c|c|c|c|c|c|}
\hline NICE & $\begin{array}{l}66.6 \% \\
75(15- \\
105)\end{array}$ & $\begin{array}{l}52.2 \% \\
62(15- \\
105)\end{array}$ & $\begin{array}{l}51.4 \% \\
143 \\
(35- \\
245)\end{array}$ & $\begin{array}{l}57.8 \% \\
67(15- \\
105)\end{array}$ & $\begin{array}{l}46.7 \% \\
76(20- \\
140)\end{array}$ & $\begin{array}{l}40.0 \% \\
49(10- \\
70)\end{array}$ & $52.46 \%$ & YwM \\
\hline WHO & $\begin{array}{l}75.6 \% \\
83(15- \\
105)\end{array}$ & $\begin{array}{l}80.0 \% \\
87(15- \\
105)\end{array}$ & $\begin{array}{l}94.2 \% \\
232 \\
(35- \\
245)\end{array}$ & $\begin{array}{l}78.9 \% \\
86(15- \\
105)\end{array}$ & $\begin{array}{l}78.3 \\
\% \\
140 \\
(20- \\
140)\end{array}$ & $\begin{array}{l}65.0 \% \\
49(10- \\
70)\end{array}$ & $78.6 \%$ & $Y$ \\
\hline $\begin{array}{c}\text { South } \\
\text { Australian }\end{array}$ & $\begin{array}{l}70.0 \% \\
78(15-105)\end{array}$ & $\begin{array}{l}51.1 \% \\
61(15-105)\end{array}$ & $\begin{array}{l}52.4 \% \\
145(35-245)\end{array}$ & $\begin{array}{l}74.4 \% \\
82(15-105)\end{array}$ & $\begin{array}{l}50.8 \% \\
81(20-81)\end{array}$ & $\begin{array}{l}21.7 \% \\
23(10-70)\end{array}$ & $53.4 \%$ & YwM \\
\hline $\mathbf{R C} \phi \mathbf{M}$ & $\begin{array}{l}28.9 \% \\
41(15- \\
105)\end{array}$ & $\begin{array}{l}31.1 \% \\
43(15- \\
105)\end{array}$ & $\begin{array}{l}54.8 \\
150 \\
(35- \\
245)\end{array}$ & $\begin{array}{l}51.1 \% \\
61(15- \\
105)\end{array}$ & $\begin{array}{l}35.0 \% \\
62(20- \\
140)\end{array}$ & $\begin{array}{l}20.0 \% \\
22(10- \\
70)\end{array}$ & $36.8 \%$ & YwM \\
\hline $\begin{array}{l}\text { Mean } \\
\text { domain } \\
\text { score }\end{array}$ & $67.0 \%$ & $55.8 \%$ & $68.8 \%$ & $68.8 \%$ & $56.7 \%$ & 48.74 & & \\
\hline
\end{tabular}

Domain scores were calculated by the following formula: (obtained score - minimum possible score)/(maximum possible score - minimum possible score). The maximum possible score was: maximum possible score $\times$ number of items in domain $\times$ number of appraisers. The minimum possible score was: minimum possible score $\times$ number of items in domain $\times$ number of appraisers Overall quality scores (OQS) and inter-reader variability (Fleiss' kappa)

$\mathrm{Y}=\mathrm{Yes} \mathrm{YwM}=\mathrm{Yes}$ with modifications

Table 3. Summary of recommendations

\begin{tabular}{|c|c|c|c|c|c|c|c|c|}
\hline & & ACOG & RCOG & Austrian & Spanish & Mexican & SOGC & NICE \\
\hline \multirow[t]{5}{*}{$\begin{array}{l}\text { Prevention } \\
\text { of tears }\end{array}$} & $\begin{array}{l}\text { Warm compresses } \\
\text { at } 2 \text { nd stage }\end{array}$ & $\begin{array}{l}\text { Level } \\
\text { A }\end{array}$ & $\begin{array}{l}\text { Level I++, } \\
\text { Grade A }\end{array}$ & $\begin{array}{l}\text { Level } \\
1 \mathrm{~A}, \\
\text { Grade A }\end{array}$ & $\begin{array}{l}\text { Level } \\
1 \mathrm{~A}\end{array}$ & 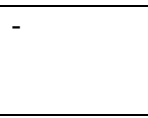 & & $\begin{array}{l}\text { Level } \\
2+\end{array}$ \\
\hline & $\begin{array}{l}\text { Perineal massage } \\
\text { at 2nd stage } \\
\text { recommended }\end{array}$ & $\begin{array}{l}\text { Level } \\
\text { B }\end{array}$ & & & & - & & \\
\hline & $\begin{array}{l}\text { Perineal massage } \\
\text { not recommended }\end{array}$ & & - & - & $\begin{array}{l}\text { Level } \\
2+, \\
\text { Grade A }\end{array}$ & & & $\begin{array}{l}\text { Level } \\
1+\end{array}$ \\
\hline & $\begin{array}{l}\text { Perineal protection } \\
\text { at crowning }\end{array}$ & - & $\begin{array}{l}\text { Level II+, } \\
\text { Grade C }\end{array}$ & - & $\begin{array}{l}\text { Level } \\
1+, \\
\text { Grade A }\end{array}$ & - & $\begin{array}{l}\text { Level } \\
\text { II-2, } \\
\text { Grade } \\
\text { A }\end{array}$ & \\
\hline & $\begin{array}{l}\text { Local anaesthetic } \\
\text { spray should not } \\
\text { be used }\end{array}$ & - & - & - & $\begin{array}{l}\text { Level } \\
2+, \\
\text { Grade B }\end{array}$ & - & & $\begin{array}{l}\text { Level } \\
1+\end{array}$ \\
\hline \multirow[t]{4}{*}{$\begin{array}{l}\text { Episiotomy/ } \\
1 \text { st and } 2 \text { nd } \\
\text { degree tear }\end{array}$} & $\begin{array}{l}\text { Restrictive } \\
\text { episiotomy }\end{array}$ & $\begin{array}{l}\text { Level } \\
\text { A }\end{array}$ & - & $\begin{array}{l}\text { Level } \\
1 \mathrm{~A}, \\
\text { Grade A }\end{array}$ & $\begin{array}{l}\text { Level I+, } \\
\text { Grade A }\end{array}$ & & & $\begin{array}{l}\text { Level } \\
1+\end{array}$ \\
\hline & $\begin{array}{l}\text { Medio-lateral } \\
\text { episiotomy }\end{array}$ & $\begin{array}{l}\text { Level } \\
\text { B }\end{array}$ & $\begin{array}{l}\text { Level III, } \\
\text { Grade D }\end{array}$ & $\begin{array}{l}\text { Level } \\
1 \mathrm{~A}, \\
\text { Grade A }\end{array}$ & $\begin{array}{ll}\text { Level } & 1 \\
+, & \\
\text { Grade } \mathrm{A}\end{array}$ & $\begin{array}{l}\text { Level 2, } \\
\text { Grade A }\end{array}$ & $\begin{array}{l}\text { Level } \\
\text { II-2, } \\
\text { Grade } \\
\text { B }\end{array}$ & $\begin{array}{l}\text { Level } \\
3\end{array}$ \\
\hline & $\begin{array}{l}\text { Episiotomy for all } \\
\text { instrumental } \\
\text { deliveries }\end{array}$ & - & $\begin{array}{l}\text { Level II-, } \\
\text { Grade D }\end{array}$ & - & $\begin{array}{l}\text { Level 3, } \\
\text { Grade D }\end{array}$ & $\begin{array}{l}\text { Level II, } \\
\text { Grade A }\end{array}$ & & \\
\hline & $\begin{array}{l}\text { First-degree tears } \\
\text { should be sutured } \\
\text { in order to improve } \\
\text { healing, unless the } \\
\text { edges of the skin }\end{array}$ & - & - & - & - & & & $\begin{array}{l}\text { Level } \\
1+\end{array}$ \\
\hline
\end{tabular}




\begin{tabular}{|c|c|c|c|c|c|c|c|c|}
\hline & are close together. & & & & & & & \\
\hline & $\begin{array}{l}\text { Continuous and } \\
\text { subcuticular suture } \\
\text { for } 2 \text { nd degree }\end{array}$ & $\begin{array}{l}\text { Level } \\
\text { B }\end{array}$ & - & - & $\begin{array}{l}\text { Level } \\
1+, \\
\text { Grade A }\end{array}$ & - & & $\begin{array}{l}\text { Level } \\
1+\end{array}$ \\
\hline & $\begin{array}{l}\text { Glue or suture for } \\
\text { perineal skin }\end{array}$ & $\begin{array}{l}\text { Level } \\
\text { B }\end{array}$ & - & - & $\begin{array}{l}\text { Level } \\
1+, \\
\text { Grade A }\end{array}$ & - & & \\
\hline OASIS & $\begin{array}{l}\text { Rectal } \\
\text { examination }\end{array}$ & & Level II+ & & - & - & $\begin{array}{l}\text { Level } \\
\text { II-2, } \\
\text { Grade } \\
\text { B } \\
\end{array}$ & $\begin{array}{l}\text { Level } \\
2+\end{array}$ \\
\hline & $\begin{array}{l}\text { Use of antibiotics } \\
\text { for OASIS }\end{array}$ & $\begin{array}{l}\text { Level } \\
\text { A }\end{array}$ & $\begin{array}{l}\text { Level 1-, } \\
\text { Grade B }\end{array}$ & $\begin{array}{l}\text { Level 2, } \\
\text { Grade B }\end{array}$ & & & $\begin{array}{l}\text { Level } \\
\text { I, } \\
\text { Grade } \\
\text { A }\end{array}$ & \\
\hline & $\begin{array}{l}\text { Full thickness } \\
\text { external anal } \\
\text { sphincter } \\
\text { laceration- end to } \\
\text { end or overlap } \\
\text { repair }\end{array}$ & $\begin{array}{l}\text { Level } \\
\text { A }\end{array}$ & $\begin{array}{l}\text { Level1++, } \\
\text { Grade A }\end{array}$ & $\begin{array}{l}\text { Level 1, } \\
\text { Grade A }\end{array}$ & - & - & $\begin{array}{l}\text { Level } \\
\text { III }\end{array}$ & \\
\hline & $\begin{array}{l}\text { Partial thickness } \\
\text { external anal } \\
\text { sphincter- end to } \\
\text { end }\end{array}$ & - & $\begin{array}{l}\text { Level } 4, \\
\text { Grade D }\end{array}$ & - & - & - & & \\
\hline & $\begin{array}{l}\text { 3.0 Polyglactin or } \\
\text { 3.0 Monofilament } \\
\text { Polydioxanone for } \\
\text { internal anal } \\
\text { sphincter }\end{array}$ & $\begin{array}{l}\text { Level } \\
\text { C }\end{array}$ & $\begin{array}{l}\text { Level 1-, } \\
\text { Grade B }\end{array}$ & $\begin{array}{l}\text { Level 3, } \\
\text { Grade B }\end{array}$ & - & $\begin{array}{l}\text { Level I, } \\
\text { Grade B }\end{array}$ & $\begin{array}{l}\text { Level } \\
\text { II }\end{array}$ & \\
\hline & $\begin{array}{l}\text { Anorectal mucosa- } \\
\text { continuous or } \\
\text { interrupted }\end{array}$ & - & $\begin{array}{l}\text { Level } 4, \\
\text { Grade D }\end{array}$ & - & - & - & & \\
\hline & $\begin{array}{l}\text { Internal anal } \\
\text { sphincter - } \\
\text { interrupted or } \\
\text { mattress suture- } \\
\text { no overlapping } \\
\end{array}$ & - & $\begin{array}{l}\text { Level } 2+, \\
\text { Grade C }\end{array}$ & - & - & - & & \\
\hline & $\begin{array}{l}\text { 3.0 Polyglactin for } \\
\text { anal mucosa }\end{array}$ & - & $\begin{array}{l}\text { Level } 4, \\
\text { Grade D }\end{array}$ & - & - & - & & \\
\hline & $\begin{array}{l}\text { Burying surgical } \\
\text { knots beneath } \\
\text { perineal muscle in } \\
\text { OASIS repair to } \\
\text { avoid migration } \\
\text { through the skin }\end{array}$ & - & $\begin{array}{l}\text { Level 1-, } \\
\text { Grade B }\end{array}$ & - & - & - & & \\
\hline & $\begin{array}{l}\text { OASIS should be } \\
\text { repaired by trained } \\
\text { practitioners }\end{array}$ & - & $\begin{array}{l}\text { Level 1-, } \\
\text { Grade D }\end{array}$ & $\begin{array}{l}\text { Level } 4, \\
\text { Grade C }\end{array}$ & - & - & & \\
\hline & $\begin{array}{l}\text { Repair of OASIS } \\
\text { can be postponed } \\
\text { for up to } 12 \mathrm{~h}\end{array}$ & - & - & $\begin{array}{l}\text { Level } \\
1 \mathrm{~B}, \\
\text { Grade B }\end{array}$ & - & - & $\begin{array}{l}\text { Level } \\
\text { I, } \\
\text { Grade } \\
\text { A }\end{array}$ & \\
\hline & Use laxatives & $\begin{array}{l}\text { Level } \\
\text { C }\end{array}$ & $\begin{array}{l}\text { Level 2+, } \\
\text { Grade C }\end{array}$ & & & & $\begin{array}{l}\text { Level } \\
\text { I, } \\
\text { Grade } \\
\text { A }\end{array}$ & \\
\hline & $\begin{array}{l}\text { Bulking agents not } \\
\text { recommended }\end{array}$ & - & $\begin{array}{l}\text { Level 1-, } \\
\text { Grade B }\end{array}$ & - & - & - & $\begin{array}{l}\text { Level } \\
\text { I, } \\
\text { Grade } \\
\text { A }\end{array}$ & \\
\hline & $\begin{array}{l}\text { Avoid rectal } \\
\text { examination in the } \\
\text { puerperium if }\end{array}$ & - & - & $\begin{array}{l}\text { Level } 4, \\
\text { Grade C }\end{array}$ & - & - & & \\
\hline
\end{tabular}




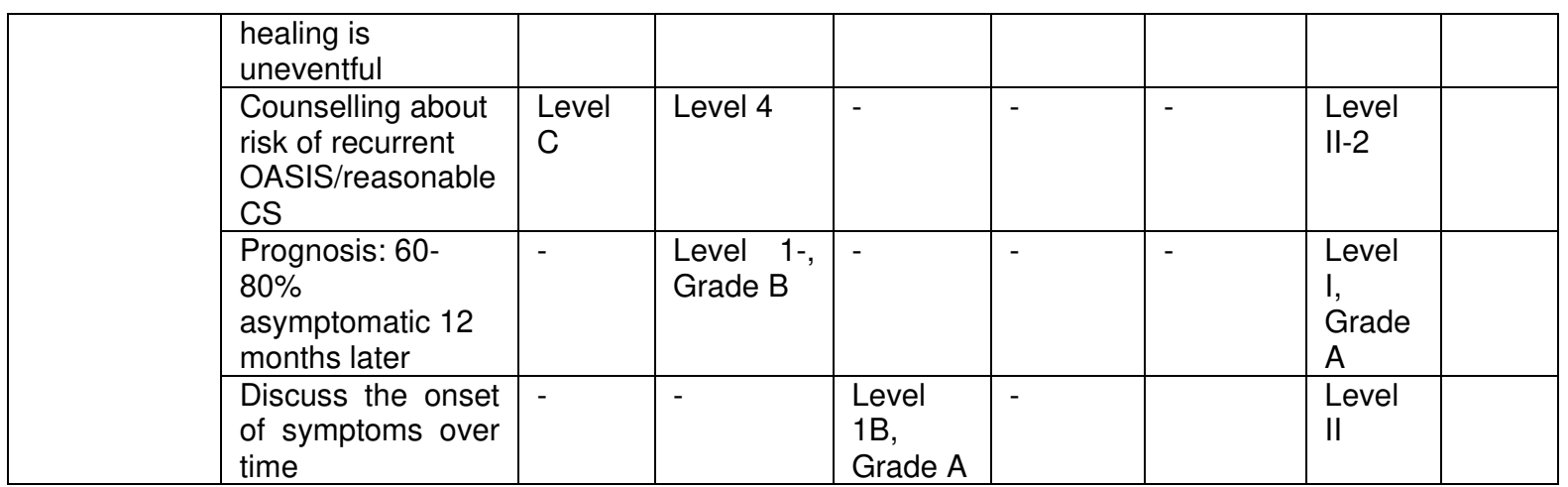

